\title{
58. Where is reality? Is It In the painting?: The representation of problematised reality in Peter Ackroyd's Chatterton'
}

\section{Zeynep Rana TURGUT²}

\begin{abstract}
APA: Turgut, Z. R. (2021). Where is reality? Is It In the painting?: The representation of problematised reality in Peter Ackroyd's Chatterton. RumeliDE Dil ve Edebiyat Araşturmaları Dergisi, (23), 924-934. DOI: 10.29000/rumelide.954200.
\end{abstract}

\begin{abstract}
The detective fiction genre undergoes a radical change along with the thematic and structural innovations brought about by postmodernism in the second half of the twentieth century. The most recognisable changes are inconclusive endings with no resolution; eager characters and vain engagement in certain incidents though there is no crime to be investigated, and the reader's newly assigned role i.e. that of the detective. The aim of this paper is to explore Peter Ackroyd's Chatterton with regard to the changing features of the detective genre. Chatterton is not labelled a pure example of detective fiction despite various use of thematic and structural elements exclusive to this genre. Ackroyd reshapes and employs the conventional components of detective fiction according to his authorial needs. Thus the focus of this paper is on Ackroyd's reformulation of traditional detective fiction in Chatterton. The emphasis is on structural and thematic affinities and differences between traditional and contemporary detective novels. The analysis is mainly based on the intertextual representation of the perception of the real and the unreal.
\end{abstract}

Keywords: Peter Ackroyd, Chatterton, postmodernism, detective fiction, real vs unreal

\section{Gerçek nerede? Resimde mi?: Peter Ackroyd'un Chatterton adlı romanında sorunlu gerçekliğin temsili}

\author{
$\ddot{\mathbf{O} z}$
}

Polisiye roman türü, yirminci yüzyılın ikinci yarısında postmodernizmin getirdiği tematik ve yapısal yeniliklerle birlikte köklü bir değişime uğrar. En tanınabilir değişiklikler çözümsüz sonuçsuz sonlardır ve soruşturulacak bir suç olmamasına rağmen bazı olaylarda dedektif rolünü üstlenmiş karakterlerin boşuna uğraştığı vakalar ve okuyucunun yeni atanan rolü, yani dedektif rolü olmuştur. $\mathrm{Bu}$ makalenin amacı, Peter Ackroyd'un Chatterton adlı romanını dedektif türünün değişen özellikleri açısından incelemektir. Chatterton, bu türe özgü tematik ve yapısal unsurların çeşitli kullanımına rağmen, saf bir dedektif kurgu örneği olarak tanımlanmamıştır. Ackroyd, polisiye kurgunun geleneksel bileşenlerini yazarının ihtiyaçlarına göre kullanır ve yeniden şekillendirir. Dolayısıyla bu makalenin odak noktası, Ackroyd'un Chatterton'daki geleneksel dedektif kurgusunu yeniden formüle etmesidir. Vurgu, geleneksel ve çă̆daş polisiye romanları arasındaki yapısal ve tematik yakınlıklar ve farklılıklar üzerindedir. Analiz ise esas olarak gerçek ve gerçek olmayan algısının metinlerarası temsiline dayanmaktadır.

This article was created from the third chapter of my PhD. Dissertation titled "Postmodern Rewriting of Detective Fiction: Reformulating the Convention of Traditional Detective Fiction in The Collector, Chatterton and When We Were Orphans"

2 Dr. Öğr. Gör., Atılım Üniversitesi, Fen Edebiyat Fakültesi, İngiliz Dili ve Edebiyatı Bölümü (Ankara, Türkiye), rana.selimoglu@atilim.edu.tr, ORCID ID: oooo-0003-2048-966X [Araştırma makalesi, Makale kayıt tarihi: 26.04.2021-kabul tarihi: 20.06.2021; DOI: 10.29000/rumelide.954200]

Adres | Address

RumeliDE Dil ve Edebiyat Araşttrmaları Dergisi $\quad$ RumeliDE Journal of Language and Literature Studies Osmanağa Mahallesi, Mürver Çiçeği Sokak, No:14/8 $\quad$ Osmanağa Mahallesi, Mürver Çiçeği Sokak, No:14/8

Kadıköy - İSTANBUL / TÜRKIYE 34714 Kadıköy - ISTANBUL / TURKEY 34714 e-posta: editor@rumelide.com

e-mail: editor@rumelide.com

tel: +90 505 7958124, +90 2167730616 phone: +90 505 7958124, +90 2167730616 
Anahtar kelimeler: Peter Ackroyd, Chatterton, postmodernism, polisiye kurgu, gerçek-gerçek olmayana karşı

\title{
1. Introduction
}

What is reality? How can reality be discovered? Is there an objective reality on which all can agree? These are the questions that have been answered differently as a consequence of the different perceptions of people and writers in different periods. For seventeenth and eighteenth century reality is accepted as the reflection of the ideal world: "mechanical world which consists of physical particles in motion is the ultimate reality" (Abrams, 1993b: 7). Artists, authors and poets either imitate nature or works of the past and that is the reason why art is accepted as a form of objective imitation and it is considered to be objective. In the Romantic period, however, nature is again used as the source but this time mixed with the artist's power of imagination which makes the work highly subjective. In the second half of the nineteenth century realism prevails which represents life and social world as what it is, in other words it attempts to recreate reality as it is (Abrams, 1993a: 174). However, after the first world war with modernism changes are observed in the subjects, forms and styles in literature and as well as other arts (Abrams, 1993a: 118). The concept of reality is believed to be subjective as well as relative; and it could be found in the "dark places of one's psychology" (Woolf, 1990: 90). Although finding out reality is the key issue in traditional detective fiction so as to resolve the case or find out the actual culprit, the complexity of deciding what is real or not in defining reality in postmodernism and postmodern works has been a major concern. In his book Literary Criticism: An Introduction to Theory and Practice Bressler points out that as Derrida and other poststructuralists suggest, there is no such thing as objective reality. They believe that all definitions and depictions of reality are subjective and are the creation of the human mind. Reality itself is relative and depends on the nature and variety of cultural and social influences on a person's life. Thus, it is perceived and interpreted differently by different viewpoints (2007: .234). The idea is parallel to that of postmodern writers whose understanding of reality is based on interpretations. Peter Ackroyd's Chatterton is one of the examples of postmodern novel where reality is problematised. There is also a series of unresolved strange coincidences which the main character Charles meets when he is in search of the truth behind the actual identity of the figure in the painting he has found. Ackroyd's novelistic techniques, his use of time, space and characters help to keep the discussion between real and unreal alive.

Peter Ackroyd's works include various postmodern techniques like pastiche, historiographic metafiction, intertextuality and parody which is one of the reasons why he is introduced as a postmodern writer. Although Peter Ackroyd is introduced as a postmodern writer, when the author is asked about his preferred novelistic techniques, the answer is brief in that, Ackroyd states that the English language is his only medium in the construction of his idiosyncrasy. In one interview, Susana Onega asks Ackroyd if his way of mingling the visionary and the pantomimic is postmodern, Ackroyd states that:

\begin{abstract}
No, it's English. It's a completely different thing. This combination of high and low, farce and tragedy, is something which is innate in the English tradition. Dickens, of course, is the great example. Shakespeare, too. And you talk about pantomime and vaudeville. That's also a very innately English sensibility at work. And as far as I am concerned, it's just part of the inheritance that goes back as far as a thousand years. It's nothing really to do with postmodernism (qtd. in Lewis, 2007: 180-181).
\end{abstract}

At the very beginning of his article "Abandoning the Postmodern? The Case of Peter Ackroyd" Aleid Fokkema gives a list of writers and questions whether such writers as Angela Carter, D.M. Thomas,

\footnotetext{
Adres
RumeliDE Dil ve Edebiyat Araştırmaları Dergisi Osmanağa Mahallesi, Mürver Ciçeği Sokak, No:14/8 Kadıköy - İSTANBUL / TÜRKIYE 34714 e-posta: editor@rumelide.com tel: +90 505 7958124, +90 2167730616

Address

RumeliDE Journal of Language and Literature Studies

Osmanağa Mahallesi, Mürver Çiçeği Sokak, No:14/8

Kadıköy - ISTANBUL / TURKEY 34714

e-mail: editor@rumelide.com,

phone: +90 $5057958124,+902167730616$
} 
Where is reality? Is It In the painting?: The representation of problematised reality in Peter Ackroyd's Chatterton / Z. R. Turgut (pp. 924-934)

Alasdair Gray and Peter Ackroyd are accepted as being within the canon of British postmodernism as representatives of the new generation or not. In their works they deal with "historiography, language and the body of the texts, the absence of origins, the issue of representation and the plurality of worlds" (1993: 168). Although Peter Ackroyd in most of his interviews rejects being labelled a writer of any particular movement, most of his works are read from a postmodern point of view due to the points mentioned above.

Chatterton, which was published and shortlisted for the Booker Prize in 1987, is an example of Peter Ackroyd's postmodern fiction. In her book The Politics of Postmodernism, Linda Hutcheon claims that "Peter Ackroyd's Chatterton offers a working example of a postmodern novel whose form and content de-naturalize representation in both visual and verbal media in such a way as to illustrate well the deconstructive potential of parody" (1989: 95). Susana Onega also defines Chatterton as "Ackroyd's most 'metafictional' historiographic metafiction" (1998: 34). Obviously, Chatterton might also be read as a postmodern detective novel. Classical detective fiction, which has a clear structure, is suitable for the postmodern writers to reshape and subvert the form in accordance with their needs. Kathleen Belin Owen puts forth in her article "The Game's Afoot: Predecessors and Pursuits of a Postmodern Detective Novel" that people can think of "postmodernism as inventing such deconstructive inversion, but these inversions actually find their beginnings within the very tradition of British ratiocinative detective fiction" (1997: 73). Postmodernist writers confuse the reader's mind by giving the role of the detective to them; the open endings which are inconclusive are also confusing. In other words, a postmodern detective story is demanding on the part of the reader as they need to interpret the text. In Chatterton, there is no murder whose perpetrator needs to be caught but there are other crimes such as literary forgery and plagiarism that are explicitly committed by all the characters in the novel. However, finding who the forgers are and why they attempt forgery are not the cases to be solved. Ackroyd's authorial intention in adding crimes like forgery and plagiarism is to reveal the duality and ambivalence between the real and the unreal. The main issue that makes the work a detective fiction is the enigmatic case to be solved that is finding the truth about the famous poet and the title character, Thomas Chatterton. The painting pictures the mysterious death of the poet, Chatterton. In the article titled "The Game's Afoot: On the Trail of the Metaphysical Detective Story" Patricia Merivale and Susan Elizabeth Sweeney mention Chatterton as a research novel which is the subgenre of metaphysical detective story "in which finding the "missing person" characteristically leads, as in other instances of fictional stalking, to discovering that we are him or her" (1999: 20). Merivale and Sweeney define metaphysical detective story as "a text that parodies or subverts traditional detective story conventions..." (1999: 2). Sometimes roles that are attributed to the detectives are transferred to the reader, or sometimes all the clues are collected in order to solve a case but these clues never contribute to finding the truth as happens in Chatterton and there is also no resolution at the end.

Chatterton consists of fifteen chapters that are divided into three parts. The novel's time span covers three different centuries: the eighteenth, nineteenth and twentieth, and in each century, an author plays an important role. The title character, the famous poet Thomas Chatterton, lives in the eighteenth century and he is the key figure throughout the novel. In the nineteenth century another author, George Meredith, poses as the model of Henry Wallis, who is painting Chatterton's death-bed scene. In the twentieth century Charles Wychwood, another writer, finds this painting by coincidence and decides to look deeper into it, as the drawn figure is the one whom he has been searching for years. The figure in the painting belongs to an eighteenth century poet, Thomas Chatterton. Charles and his close friend, Philip, start doing research to unveil the secret behind the painting. While in search of the secret behind the painting, they discover that the painter of the picture is another poet albeit from the

Adres Address

RumeliDE Dil ve Edebiyat Araşturmalar Dergisi $\quad$ RumeliDE Journal of Language and Literature Studies Osmanağa Mahallesi, Mürver Çiçeği Sokak, No:14/8 Osmanağa Mahallesi, Mürver Çiçeği Sokak, No:14/8 Kadıköy - İSTANBUL / TÜRKIYE 34714 Kadıköy - ISTANBUL / TURKEY 34714 e-posta: editor@rumelide.com e-mail: editor@rumelide.com, tel: +90 505 7958124, +90 2167730616 phone: +90 505 7958124, +90 2167730616 
nineteenth century, George Meredith. So three authors from three different centuries come together by means of a painting: Thomas Chatterton, George Meredith and Charles Wychwood. Charles is the one who is quite sure that he is able to understand the relation between the painter and the poet and what happened to the person portrayed in this painting. Although he has not been writing and earning almost nothing for a long time, this problem-solving game could be an inspiration for him to write again and earn money.

\section{Real vs unreal: The investigation starts with the painting}

Peter Ackroyd starts the novel first with an encyclopaedic biography of Thomas Chatterton and the reader is informed about the short life of the poet and the reason for his death. This biographical information is followed by short extracts from the novel that introduce the key characters of each century and from that point on the discussion between the real and the unreal starts. In the second extract it is George Meredith who talks about his modelling for Henry Wallis's painting: "Yes, I am a model poet', Meredith was saying. 'I am pretending to be someone else'” (Ackroyd, 1987: 2). Meredith, who feels uncomfortable while trying to pretend to be someone else, wonders who would be immortalised as a result of this painting: "But will it be Meredith or will it be Chatterton?" (Ackroyd, 1987: 3) In the first chapter of the novel Charles finds the painting and takes it to his house but his son Edward's immediate reaction to it is quite strange. He says: "It is a fake" (Ackroyd, 1987: 14) and he repeats the statement whenever he sees the painting. However, it seems quite real to Charles. The discovery of it initiates the discussion between real and unreal and from that moment onwards the novel's plot turns out to be a detective story. In her book titled Writing History as a Prophet: Postmodernist Innovations of the Historical Novel Elizabeth Wesseling emphasizes the "double story" that the detective novel has. Before the story begins the crime has already been committed and the detective deals with solving the mystery behind it. "The detective relates the crime which has been committed before the narrative within the novel begins, but the major plot deals with the unravelling of the crime" (1991: 90). Apart from plagiarism and forgery, there is no crime in the traditional detective sense committed by anybody in Chatterton but the way Charles examines the figure in the painting implies that this painting has something mysterious about it as if a series of events have already taken place before. That is the reason why Charles and his close friend Philip follow the almost identical investigation method of Arthur Conan Doyle's Sherlock Holmes and Dr Watson. In the novel, Charles often calls Philip "Holmes" which means they will search for the truth behind the painting with the sensibility of detectives: "This is the mystery, Holmes. Once I've solved it, I'm a rich man" (Ackroyd, 1987: 18). In the novel there are many intertextual references ranging from Blake to T.S. Eliot and self-quotations from Chatterton and Meredith. Arthur Conan Doyle's Sherlock Holmes is also another intertext as Ackroyd attributes Sherlock Holmes' and Dr Watson's roles to his characters Philip and Charles. However, Ackroyd's characters' social, educational and cultural backgrounds show incompatibility with fictional predecessors. Sherlock Holmes represents urban life by wearing a deerstalker cap and using the train carriage and hansom cab as his means of transportation. By creating such a man of the city, Doyle wants to show a significant change in Victorian society in which aristocratic country estates no longer have the same effect in making the significant decisions it is rather "industrialists of Birmingham, Manchester and Bradford" who are the effective voice of making important decisions (Paul 1991: 46). As a character, Holmes is the exact representation of the hero of his society because he is "strong, masculine and man of action" (Smith, 1996: 120). Sherlock Holmes is the representative of aristocracy who "works not to live but lives to work" (Rzepka, 2005: 47). His companion Dr Watson is as clever as Holmes and is a well-educated and cultured man whereas "both men [Charles and Philip] had come from poor London families, and on occasions

\footnotetext{
Adres $\mid$ Address

RumeliDE Dil ve Edebiyat Araşttrmaları Dergisi $\quad$ RumeliDE Journal of Language and Literature Studies Osmanağa Mahallesi, Mürver Çiçeği Sokak, No:14/8 Osmanağa Mahallesi, Mürver Çiçeği Sokak, No:14/8 Kadıköy - İSTANBUL / TÜRKIYE 34714 Kadıköy - ISTANBUL / TURKEY 34714 e-posta: editor@rumelide.com e-mail: editor@rumelide.com, tel: +90 505 7958124, +90 2167730616 phone: +90 505 7958124, +90 2167730616
} 
Where is reality? Is It In the painting?: The representation of problematised reality in Peter Ackroyd's Chatterton / Z. R. Turgut (pp. 924-934)

Charles amused Philip with this extravagant parodies of an 'upper class' accent" (Ackroyd, 1987: 22). Compared to Holmes and Dr Watson, Charles and Philip are too weak and insufficient to solve a mystery. Charles's illness is also a handicap for him. However, like Charles, Philip also senses something awkward about the painting while he is "looking at the face on the canvas" (Ackroyd, 1987: 21) and they both take part in the research. It should be Thomas Chatterton whose portrait he has in his own house. However, in Charles's painting Chatterton looks older which is surprising because according to the records: "Thomas Chatterton, the faker of medieval poetry and perhaps the greatest literary forger of all time. Born in 1752 and, died by his own hand in 1770" (Ackroyd, 1987: 21). If he died at a young age, he cannot be the figure in Charles's painting, thus, Charles believes that there should be some clues about the past. Like a careful detective, Charles continues his research on Chatterton and eventually comes to the conclusion that Chatterton invented his own death scenario. Charles explains this to Philip: 'If he was born', he was saying, 'I mean - if this is right. If he was born in 1752 , and the portrait was painted in 1802 , that would make him fifty years old.' He looked at the middle-aged man depicted on the canvas. ...'which would mean - that Chatterton didn't die' (Ackroyd, 1987: 23). For Charles "Chatterton faked his own death" (Ackroyd, 1987: 23). From that point on his aim is to prove it. He puts the painting on the wall and says: "We're going to investigate you" (Ackroyd, 1987: 41). Then he points to the figure in the painting and talks to him: "We're going to find your secrets" (Ackroyd, 1987: 42). His starting point is the antique shop where he trades his books with the painting. He obtains the vendor's name and address then an in-depth study of Philip and Charles on the painting starts which Charles calls "the quest": "'The quest begins on Saturday,' Charles said excitedly. 'Oh do not ask what is it. Let us go and make our visit!'" (Ackroyd, 1987: 45). The investigation continues in Bristol with some documents collection. Philip and Charles's investigation taking place in the streets is reminiscent of American hard-boiled detective fiction in which the setting moved from the classical story's rural location to American cities and streets that were full of crime and evil (Holzapfel, 1996: 17). As a result of the investigation, Charles and Philip find some documents and in these documents a different scenario about Chatterton's death is written. According to this scenario, Charles seems to be right because it explains that at the age of eighteen, Chatterton fakes his suicide which was advised by his bookseller Samuel Joynson so as to continue to write fake poems by using the names of dead poets. In order to be sure of his findings, Charles continues his investigation by showing a page from the Chatterton documents to one of his friends, Andrew Flint, who "has acquired a reputation both as a novelist and a biographer" (Ackroyd, 1987: 65). During his university years Flint was interested in palaeography, so Charles believes that Flint would give a date about the inscription of the document. When he examined the document with its paper and handwriting, Flint says it is "the Durham watermark" and he continues:

The punctuation and the capitals have been rationalised but, on the other hand... Is that a pun? Gracious me. On the other hand, there is no real contrast between the thick and the thin strokes. Do I dare to give a date? ...Yes I dare. Expertocrede, dear Charles, and not me. But I would suggest before 1830. (Ackroyd, 1987: 74)

Flint also added that the Durham watermark was not used before 1790, so Charles gets really excited as he is right about his discovery about Chatterton. However, in the final chapter, another scenario about Chatterton's death appears. Chatterton tries to cure himself of gonorrhoea with arsenic and a phial of laudanum but he kills himself accidentally. Although there is biographical information at the very beginning of the novel which is informative enough to have an idea of the short life of Thomas Chatterton, with Charles's suspicious approach to the poet's death, the reader begins to question the truthfulness of this biographical information as well. Ackroyd gives different death scenarios of Chatterton but defining the real one is really difficult, so what Ackroyd tries to show is the ambiguity of

Adres Address

RumeliDE Dil ve Edebiyat Araşttrmaları Dergisi $\quad$ RumeliDE Journal of Language and Literature Studies Osmanağa Mahallesi, Mürver Çiçeği Sokak, No:14/8 $\quad$ Osmanağa Mahallesi, Mürver Çiçeği Sokak, No:14/8 Kadıköy - İSTANBUL / TÜRKIYE 34714 Kadıköy - ISTANBUL / TURKEY 34714 e-posta: editor@rumelide.com e-mail: editor@rumelide.com, tel: +90 505 7958124, +90 2167730616 phone: +90 505 7958124, +90 2167730616 
reality. For Elizabeth Wesseling in her book titled Writing the History as a Prophet, Chatterton reveals the progression of literary history that is like an intricate maze of plagiarisms where the present feeds off the past and, vice versa, the past gives life to the present and she adds "the novel invents several different versions of Chatterton's life, all of which reinforce the idea that there are no clearcut, unambiguous origins" (1991:136). At this point it is possible to discuss Chatterton as a historiographic metafiction due to the novel's paradoxical, yet vivid and believable combination of fictive and historical as Hutcheon termed (1989: 14-15). Ackroyd represents Chatterton with historical/biographical data at the beginning but later draws a poet figure who is in need of plagiarism because of his lack of creativity. In addition to this, his alternative deaths make the reader question the truth. By doing so, Ackroyd suggests that biography and history do not always reveal one single truth but they can create alternatives. He even supports the idea that "there is no history any more" through his character, Charles's friend, Andrew Flint. "There is no history any more. There is no memory. There are no standards to encourage permanence - only novelty, and the whole endless cycle of new objects" (Ackroyd, 1987: 150).

\section{Other characters contribute in the discussion of real and unreal}

In the novel, Ackroyd's writer, critic and painter characters keep the discussion on real and unreal alive. Surprisingly, being unaware of each other, these characters are linked by a common motivation which is artistic creation and fame. Yet none of them has originality in their works as they all plagiarise in the name of inspiration. What they actually have in common are plagiarism and forgery. Thomas Chatterton is painted by Henry Wallis with the poet George Meredith's modelling. Charles Wychwood tries to write a biography about Chatterton with the documents he collected while his friend Andrew Flint writes about the life of George Meredith. Sarah Tilt writes about the Art of Death in English painting. Although they live in different times, there is a connection among these writers and painters and through this connection the real and the fictive come together. First Thomas Chatterton is called "the greatest literary forger of all time" (Ackroyd, 1987: 21) then Chatterton's painting by whoever the painter is inspires Charles to write the life of the poet although he is not sure about the reliability of the information that he found about Chatterton. However, it is not important whether the information is true or not for Charles because when it comes to creativity or writing "reality is the invention of unimaginative people" (Ackroyd, 1987: 39). When Harriet, a novelist whom Charles works for, asks a further question on this definition: "Can we imagine the reality?" Charles's answer is: "'Oh yes', he said, "it's a question of language. Realism is just as artificial as surrealism, after all.'...The real world is just a succession of interpretations. Everything which is written down immediately becomes a kind of fiction'" (Ackroyd, 1987: 40). In fact, here Ackroyd talks about the self-reflexive fiction which reflects or refers to itself as a work of fiction rather than pretending it is offering something from the real world (Nicol, 2009: 35). For Hutcheon, a self-reflexive text suggests that "narrative does not derive its authority from any reality it represents, but from the cultural conventions that define both narrative and the construct we call reality" (1989: 36). That is the reason why there is no single reality and the reality is based on interpretations. The poet George Meredith also believes that reality is hidden in the words. He is questioning if he is real or not in the painting and as a result he comes to the conclusion that "he is a forgery but his writing is not" (Ackroyd, 1987: 141) and he adds that "there is nothing more real than words. They are reality. ...I said that the words were real, Henry, I did not say that what they depicted was real" (Ackroyd, 1987: 157) which means that it is the language that is interpreted.

Another plagiarist is Harriet who plagiarises the plots of another writer, Harrison Bentley, and this is understood by Philip during his research in the library and later he tells this to Charles. However, for

\footnotetext{
\begin{tabular}{r|l} 
Adres & Address \\
RumeliDE Dil ve Edebiyat Araşttrmaları Dergisi & RumeliDE Journal of Language and Literature Studies
\end{tabular} Osmanağa Mahallesi, Mürver Çiçeği Sokak, No:14/8 Osmanağa Mahallesi, Mürver Çiçeği Sokak, No:14/8 Kadıköy - İSTANBUL / TÜRKIYE 34714 Kadıköy - ISTANBUL / TURKEY 34714 e-posta: editor@rumelide.com e-mail: editor@rumelide.com, tel: +90 505 7958124, +90 2167730616 phone: +90 505 7958124, +90 2167730616
} 
Where is reality? Is It In the painting?: The representation of problematised reality in Peter Ackroyd's Chatterton / Z. R. Turgut (pp. 924-934)

her, stealing from other writers is normal. During a conversation with Charles, Harriet claims almost all writers steal. "They'll steal any..." (Ackroyd, 1987: 100). Then Charles completes her sentences: "Anything, that's right" and he continues: "It is called the anxiety of influence" (Ackroyd, 1987: 100). The Anxiety of Influence written by Harold Bloom is another intertextual reference in Chatterton. In the book Bloom puts the emphasis on the inner life, in the psychology of the poet rather than on the content of his work. Poets are not secluded, isolated beings, instead they are living in the very heart of the society. They are subject to various physical and mental societal influences. They are naturally inspired by the poetry written before them. Yet, this feeling of deep admiration and appreciation triggers anxiety among present poets because it leads to the fear of inability to create something original. In the preface of his book titled The Anxiety of Influence: A Theory of Poetry, Bloom explains what he means by "influence" and "anxiety":

The anxiety may or may not be internalized by the later writer, depending upon temporal, spiritual, psychological - all of them ultimately defensive in their nature. What matters most (and it is the central point of this book) is that anxiety of influence comes out of a complex act of strong misreading, a creative interpretation that I call "poetic misprision". What writers may experience as anxiety, and what their works are compelled to manifest, are the consequence of poetic misprision, rather than the cause of it (1997: xxiii).

Bloomian anxiety of influence "must be true of novelists, too" says Harriet and she admits that "there are resemblances between her books and other writers" (Ackroyd, 1987: 101). In Chatterton it is Philip who has the "anxiety of influence". Since Philip's first attempt in composing a novel ended after the first forty pages, he gives up the idea of writing because he believes he could not go beyond the styles of the authors whom he admires. The point Philip defends is that inspiration should carry the author and the artist beyond the limited horizons of imitation; otherwise it is not possible to be original in the fields of literature and arts. Yet, when Philip recognises the similarities between Harrison Bentley and Harriet's works, he cannot criticise her as he believes "there were a limited number of plots in the world (reality was finite, after all) and no doubt it was inevitable that they would be reproduced in a variety of contexts" (Ackroyd, 1987: 70). There can no longer be original texts since literature is intertextual. This is the very idea of Luis J. Borges in "The Library of Babel" as he states the "certainty that everything has already been written" (1998: 118). John Barth also perceives the literature of this time as "literature of exhaustion" and continues in a time in which all literary forms are used up, a literary text can only be written "by an author who imitates the role author" and can be nothing but an imitation of another literary text (1982: 12). Both critics, who share the same opinions with Philip in Chatterton, come up with the idea that literature is nothing but a re-writing or recycling of other texts.

The final forger figure is Stewart Merk who is the painter of Seymour's last paintings. However, although these writers and painters imitate or plagiarise others, it is not possible to say that their works are unreal because they exist in a way. However, in that case multiple interpretations are possible depending on readers'/gazers' assessment of the content of the work of art. At the end of the novel Philip gives a brief summary of the book: "Everything just seems to take place, he had said, and there's not even any momentum. It's just, well, it's just velocity. And if you trace anything backwards, trying to figure out cause and effect, or motive, or meaning, there is no real origin for anything. Everything just exists. Everything just exists in order to exist" (Ackroyd, 1987: 232). This is Ackroyd's way of looking at history in that even history can be interpreted so there is no need to search for a cause and effect relationship in anything or it is unnecessary to look for a meaning because everything just happens.

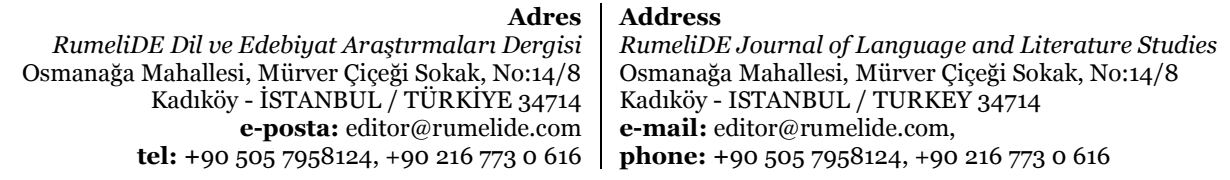

RumeliDE Dil ve Edebiyat Araştırmaları Dergisi ( Mürver Çiçeği Sokak, No:14/8 e-posta: editor@rumelide.com tel: +90 $5057958124,+902167730616$
Address

OsmeliDE Journal of Language and Literature Studies

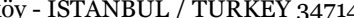

phone: +90 505 7958124, +90 2167730616 
After finishing examining all documents he and Philip found, Charles decides to write about Thomas Chatterton. One day he gets a piece of paper and starts writing his preface immediately.

Thomas Chatterton believed that he could explain the entire material and spiritual world in terms of imitation and forgery, and so sure was he of his own genius that he allowed it to flourish under other names. The documents which have recently been discovered show that he wrote in the guise of Thomas Gray, William Blake, William Cowper and many others; as a result, our whole understanding of eighteenth century poetry will have to be revised (Ackroyd, 1987: 126-127).

Charles suddenly stops as he does not know how he is going to continue. He realises that all biographers described Chatterton differently and because of these differences first Charles feels annoyed but later it is fine for him as he thinks "if there were no truths, everything was true" (Ackroyd, 1987: 127). Then Charles closes his eyes and continues writing although he runs out of ink. He "presses deeper into the paper in order to print the outlines of his words" (Ackroyd, 1987: 127). After a phone break, Charles goes back to his desk to continue writing but unfortunately his words "faded, leaving only a few hollows and striations behind" (Ackroyd, 1987: 128) and he tries to remember what he has already written but he cannot. What Charles wrote remains a mystery like the reality of Chatterton's life and death. Charles gets worse day by day and he dies without fulfilling his aim of revealing the secret behind Chatterton's life. After his death, his friend Philip decides to write about Chatterton which was his friend's dream " ... I tried writing my own novel but it didn't work, you know. I kept on imitating other people, - but now, this - with Charles's theory - I might be able to - ..." (Ackroyd, 1987: 232).

After Charles's death, Vivien gives the painting to Harriet who takes it to the Cumberland gallery in order to understand if it is real or not. It is understood that it is fake but as Harriet wants to hear that it is real, she starts questioning the meaning of real. "What is real and what is not real, don't you think?" (Ackroyd, 1987: 200). She knows that the expert Stewart Merk is a forger so Cumberland can solve the problem with the painting. However, while Merk is trying to fix the painting, he realises that there is more than one layer in it. "There are so many different layers...There's definitely another painting behind this one, and there may be more" (Ackroyd, 1987: 205). The scene which is set in the gallery is about deciphering a second picture behind the first layer of the canvas. Reality is in the layers of the painting but as is seen, there is a multiplicity of reality because of the abundant number of layers. Hence, Ackroyd achieves a multi-layered palimpsestic narrative not only through words but also through images. It can also be interpreted that there are many alternatives but unfortunately they cannot help to reach the finalisation. The layers in the painting also reminds the reader of the poststructuralist concept of "signifieds'" relations with other "signifieds". Derrida claims that the signified cannot orientate or make permanent the meaning of the signifier because the relationship between the signifier and the signified is both arbitrary and conventional. In accordance with this, signifieds often function as signifiers. In short, although structural theorists believe that reality and meaning are understood by language through the inseparable signifier and signified, in deconstruction there is no stabilised truth and reality is relative because of the relation of signifieds with other signifieds (Bressler, 2007: 119). In Chatterton, the painting is the signifier which has more than one signified. Thus, there is no single interpretation of it; it is interpreted from different perspectives and this creates the multiplicity of reality, truth and meaning.

RumeliDE Dil ve Edebiyat Araşttrmaları Dergisi Osmanağa Mahallesi, Mürver Ciçeği Sokak, No:14/8 Kadıköy - İSTANBUL / TÜRKIYE 34714 e-posta: editor@rumelide.com tel: +90 $5057958124,+902167730616$
Address

RumeliDE Journal of Language and Literature Studies

Osmanağa Mahallesi, Mürver Çiçeği Sokak, No:14/8

Kadıköy - ISTANBUL / TURKEY 34714

e-mail: editor@rumelide.com,

phone: +90 5057958124 , +90 2167730616 
Where is reality? Is It In the painting?: The representation of problematised reality in Peter Ackroyd's Chatterton / Z. R. Turgut (pp. 924-934)

\section{The narrative style and the use of space}

Compared to detective fiction from Poe to hard-boiled one, Chatterton is quite different in its narrative style. Poe's invention is the presence of a narrator as a story teller and confidant in his stories. This anonymous narrator who would be the forerunner of other narrator characters of other detective story writers tells the story. Doyle aims to create a companion like Dr. Watson to provide a narrator, who tells the story with a clear, descriptive language, in his stories. It is widely believed that Dr Watson is similar to Poe's anonymous narrator. "Poe's unnamed, faceless narrator would later be transformed and given flesh and blood by Sir Arthur Conan Doyle as Sherlock Holmes's Doctor Watson" (Smith 1996: 56). Unlike the classical novels whose first person narrator solves the problem, hard-boiled ones involve the reader as a detective as its detective is the private eye (Holzapfel, 1996: 21). In Chatterton it is possible to see the multiplicity in narrative as well. There are shifts from the third person omniscient narrator to the first person in chapter six and then to the omniscient narrator again which present the reader with different points of view. In chapter six, where Thomas Chatterton introduces himself, he tells the reader how he managed to become such a popular poet in Bristol. He combines several sources and adds his style and produces his own poetry: "I reproduc'd the Past and filled it with such Details that it was as if I were observing it in front of me: so the Language of ancient Dayes awoke the Reality itself for, tho' I knew that it was I who composed these Histories, I knew also that they were the true ones" (Ackroyd, 1987: 85). For Linda Hutcheon in chapter six which is narrated by Chatterton himself "telling us how he 'reproduced the Past' by mixing the real and the fictive in a way reminiscent of the technique of Chatterton" (1989: 97), Charles wants to create his own reality by combining biographical information with what he got from the past documents, however, what he acquires blurs his mind: "In any cases he noticed that each biography described a quite different poet: even the simplest observation by one was contradicted by another, so that nothing seemed certain" (Ackroyd, 1987: 127).

Another element which changes from period to period is the use of space. Poe gives the first examples of the "1ocked room" mysteries in his stories. In this kind of mystery, the place is important because when it is examined it looks impossible to tell that the crime was committed there as the place is sealed or locked. "The Murders in the Rue Morgue" is the first example. In this story two women are murdered in a locked room and when the room is opened the key is still in the lock inside. To Smith there are two advantages of using locked room mystery. "The advantages of the locked room mystery is that it provides two puzzles to be solved - how was the crime committed as well as who was the criminal" (1996: 57). In the Golden Age of detective fiction events generally take place in an English country house where all characters gather sometimes for a celebration or a party, in short, they have a reason to be there (Paul 1991: 86-88). In hard-boiled novels, the setting moved from the classical story's rural location to American cities and streets. In Chatterton there are shifts not only in narration but also in time and space. It combines three different stories of three successive centuries but the protagonists of each story are connected to each other and this connection meets on a single space, which is the painting. Since one of the concerns of postmodernist authors is to carry the past to the present for the past which is loaded with cultural heritage is regarded as central to their poetics. Therefore, past and present are commonly seen co-existent in postmodern fiction. Likewise, Ackroyd's fictional painting included three different authors from different centuries. Past and present are intertwined as represented at the end of the book with Charles's last utterances: "I will not wholly die, then. Two others have joined him - the young man who passes him on the stairs and the young man who sits with bowed head by the fountain - and they stand silently beside him. I will live for ever, he tells them. They link hands, and bow towards the sun" (Ackroyd, 1987: 234). Charles dies, and his

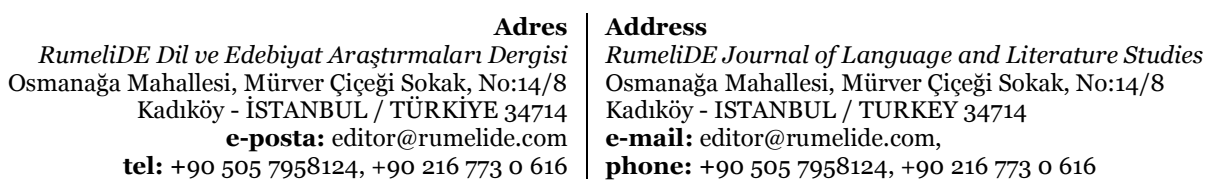


position in the hospital bed is nearly the same with the pose in Wallis' Chatterton picture. When Charles's son Edward visits the Tate Museum to see the Chatterton painting once more, he realises that the figure in the painting is like his father. "Edward had not yet chosen to look closely at the man lying upon the bed but now, when he did so, he stepped back in astonishment: it was his father lying there" (Ackroyd, 1987: 229). When Charles first saw the Chatterton painting, he never thought that he would be identified with the figure in the painting but now he is in the painting his search remains inconclusive.

\section{Conclusion}

Although Peter Ackroyd's novel Chatterton is not in the category of detective fiction, it may be read as a detective novel becuase it contains the characteristics of this genre. Therefore, the article deals with the structural and thematic similarities and differences between the traditional detective novel and its postmodern version. The main analytical part lays emphasis on intertextual representation of the idea of real and unreal.

After reading Chatterton, one can deduce that throughout the novel reality is defined and refined many times, and thus, the discussion on the real and the unreal is kept alive perpetually. The idea inferred from this discussion might be that there is no single reality; reality is multiple due to countless number of perceptions and interpretations. Even the so-callled factual historical and biographical data can be perceived by each person in a different way. Hence, it is obversed that reality can be hidden either in one of the palimpsest layers of a paninting or in a line of a poem written by one of the poets mentioned in the novel.

\section{References}

Abrams, M. H. (1993a). A glossary of literary terms. Harcourt Brace\&Company.

Abrams, M.H.. (1993b). The Norton anthology of English literature. Norton\&Company, 6(2).

Ackroyd, P. (1987). Chatterton. Grove books.

Barth, J. (1982). The literature of exhaustion and the literature of replenishment. Lord John Press.

Bloom, H. (1997). The anxiety of influence: a theory of poetry. Oxford University Press.

Borges, J. L. (1998). The library of Babel, Collected fictions. (Trans. A. Hurley). Penguin.

Bressler, C. E. (2007). Literary criticism: an introduction to theory and practice. Pearson.

Fokkema, A. (1993). Abandoning the postmodern? the case of Peter Ackroyd. In T. D'haen\& H. Bertens (Eds.), British postmodern fiction. Rodopi B.V., 167-179.

Holzapfel, A. M. (1996). The New York trilogy: whodunit?: tracking the structure of Paul Auster's anti-

detective novels. Peter Lang.

Hutcheon, L. (1989). The politics of postmodernism. Routledge.

Lewis, B. (2007). My words echo thus: possessing the past in Peter Ackroyd. University of South Carolina Press.

Merivale, P. \&Sweeney, E.S. (Eds.) (1999). Detecting texts: the metaphysical detective story from Poe to postmodernism. University of Pennsylvania Press.

Nicol, B. (2009). The Cambridge introduction to postmodern fiction. Cambridge University Press.

\begin{tabular}{r|l} 
Adres & Address \\
RumeliDE Dil ve Edebiyat Araşttrmaları Dergisi & RumeliDE Journal of Language and Literature Studies \\
Osmanağa Mahallesi, Mürver Çiçeği Sokak, No:14/8 & Osmanağa Mahallesi, Mürver Çiçeği Sokak, No:14/8 \\
Kadıköy - İSTANBUL / TÜRKIYY 34714 & Kadıköy - ISTANBUL / TURKEY 34714 \\
e-posta: editor@rumelide.com & e-mail: editor@rumelide.com, \\
phone: +90 505 7958124, +90 2167730616
\end{tabular}


Where is reality? Is It In the painting?: The representation of problematised reality in Peter Ackroyd's Chatterton / Z. R. Turgut (pp. 924-934)

Onega, S. (1998). Peter Ackroyd. Northcote House Publishers Ltd.

Owen, K. B. (1997). "The game's afoot": predecessors and pursuits of a postmodern detective novel". In J. H. Delameter\&R. Prigozy (Eds.) Theory and practice of classic detective fiction. Greenwood Press, 73-84.

Paul, R. S. (1991). Detective fiction, popular theology and society. Southern Illinois University Press. Rzepka, C. J. (2005). Detective fiction. Polity Press.

Smith, J. R. (1996). Detective fiction. Kendal/Hunt Publishing Company.

Wesseling, E. (1991). Writing history as a prophet: postmodern innovations of the historical novel. John Benjamin Company.

Woolf, V. (1990). Modern fiction. In D. Lodge (Ed.) 20 ${ }^{\text {th }}$ c. literary criticism. Longman, 1990, 86-91. 